\title{
FOXP3 wt Allele
}

National Cancer Institute

\section{Source}

National Cancer Institute. FOXP3 wt Allele. NCI Thesaurus. Code C104395.

Human FOXP3 wild-type allele is located in the vicinity of Xp11.23 and is approximately 14 $\mathrm{kb}$ in length. This allele, which encodes forkhead box protein P3, plays a role in transcription regulation and the immune response. Mutations in this gene are associated with immunodeficiency polyendocrinopathy, enteropathy, X-linked syndrome (IPEX). 